\title{
PENGARUH TERAPI MUSIK TERHADAP STATUS HEMODINAMIKA PADA PASIEN KOMA DI RUANG ICU SEBUAH RUMAH SAKIT DI LAMPUNG
}

\author{
Tori Rihiantoro*, Elly Nurachmah**, Rr. Tutik Sri Hariyati***
}

\begin{abstract}
Abstrak
Penelitian ini bertujuan mengetahui pengaruh terapi musik terhadap status hemodinamika pasien koma. Penelitian ini menggunakan desain kuasi eksperimen one group pre-post dan dengan teknik consecutive sampling didapatkan sampel 21 pasien di ruang ICU sebuah RS di Lampung. Analisis deskriptif menggambarkan bahwa sesudah terapi musik terjadi penurunan rerata MAP (6,80 $\mathrm{mmHg})$, penurunan rerata frekuensi jantung $(6,76 \mathrm{kali} / \mathrm{menit})$, dan penurunan rerata frekuensi pernapasan (4,08 kali/menit). Hasil analisis bivariat dengan tes $\mathrm{T}$ dependen menyimpulkan bahwa terdapat pengaruh yang bermakna terapi musik terhadap MAP $(p$ value $=0,031)$, frekuensi jantung $(p$ value $=0,015)$ dan frekuensi napas $(p$ value $=0,000)$. Penurunan indikator status hemodinamika pada pasien koma dengan cidera kepala dan stroke akan membantu stabilisasi hemodinamika pasien sekaligus membantu proses pemulihan pasien.
\end{abstract}

Kata kunci: status hemodinamika, terapi musik

\begin{abstract}
This research attempted to identify the effect of music therapy on hemodynamic status of coma patients. The design used was a quasi experimental one group pre-post test design with a consecutive sampling method. Twenty one samples in the ICU of a hospital in Lampung were participated in the study. The descriptive analysis showed decreasing mean of MAP (6,80 mmHg), heart rate $(6,76 \mathrm{bpm})$, and respiration rate $(4,08 \mathrm{bpm})$ after music therapy. The bivariate analysis using the dependent test showed a significant relationship of music therapy to $M A P(p$ value $=0,031)$, heart rate $(p$ value $=0,015)$ and respiration rate ( $p$ value $=0,000)$. Decreasing the hemodynamic indicators to coma patients with stroke and severe head injury could help to stabilize their hemodynamic balance and to promote faster recovery.
\end{abstract}

Key words: hemodynamic state, music therapy

\section{LATAR BELAKANG}

Pasien dalam keadaan koma, terutama dengan kasus-kasus stroke dan cidera kepala pada umumnya akan memberikan gambaran tekanan darah yang tidak stabil. Terdapat dua prinsip tipe koma yang berhubungan dengan cidera kepala dan spinal. Pada tipe yang pertama, pasien koma mengalami peningkatan tekanan darah dan tekanan intra kranial (TIK) disertai dengan penurunan frekuensi nadi dan pernapasan. Sedangkan pada tipe kedua, pasien koma tidak mengalami peningkatan TIK dan tekanan darah. Pada umumnya pasien stroke dan cidera kepala akan mengalami koma tipe pertama yaitu menunjukan tekanan darah yang tidak stabil, dimana tekanan darah umumnya meninggi tetapi pernapasan dan nadi melambat (Ghazar \& Chestnut, 1997).
Ketidakstabilan status hemodinamika pada pasien cidera kepala dan stroke akan berpengaruh terhadap TIK, sehingga akan mempengaruhi perubahan perfusi pada jaringan serebral. Dengan demikian, untuk memperbaiki perfusi jaringan serebral pasien cidera kepala dan stroke perlu dilakukan intervensi keperawatan dan medis yang menunjang percepatan pemulihannya. Kecepatan pemulihan perfusi jaringan serebral akan berdampak terhadap pemulihan dan penyembuhan kondisi pasien. Secara ekonomi, bila pasien pulih lebih cepat, maka biaya perawatan yang harus ditanggung oleh pasien akan berkurang.

Perubahan tekanan darah baik pada pasien koma maupun pasien sadar sangat dipengaruhi oleh adanya stimulus. Stimulus tersebut dapat berasal dari dalam diri sebagai manifestasi perubahan fisiologi tubuh akibat penyakit yang dideritanya. 
Selain itu, stimulus dapat juga berasal dari luar individu yang bersifat fisik maupun sosial dalam konteks lingkungan di sekitar pasien.

Status hemodinamika pada pasien koma juga dikendalikan oleh susunan syaraf pusat terutama di medula oblongata. Perubahan status hemodinamika yang diatur di dalam medula oblongata tersebut dipengaruhi oleh stimulasi sistemik. Peran baroreseptor dalam menerima stimulasi sistemik sangat berpengaruh dalam menentukan perubahan status hemodinamika nadi maupun tekanan darah. Stimulus yang diterima oleh baroreseptor berupa perubahan tekanan dalam pembuluh darah akan dikirimkan ke pusat pengaturan jantung di medula oblongata. Kemudian pusat jantung akan menentukan frekuensi dan kekuatan denyut jantung. Selanjutnya terjadilah penyesuaian-penyesuaian (kompensasi) dalam rangka mempertahankan keseimbangan.

Stimulasi sensoris merupakan tindakan untuk meningkatkan kesadaran dan potensi rehabilitasi pada pasien koma. Kegiatan stimulasi dapat berupa rangsangan pada sensori penglihatan, pendengaran, penciuman, perasa, perabaan, dan kinestesia. Diantara beberapa stimulus sensoris tersebut, stimulus terhadap pendengaran dengan memperdengarkan terapi musik adalah yang paling banyak diteliti oleh para ahli.

Terapi musik merupakan salah satu bentuk intervensi keperawatan yang dapat dilakukan oleh perawat sebagai stimulasi kapada pasien yang diharapkan dapat berdampak terhadap pemulihan dan penyembuhan pasien. Terapi musik yang diberikan kapada pasien cidera kepala dan stroke dengan penurunan kesadaran akan memberikan stimulasi pada sistem syaraf untuk menciptakan kestabilan status hemodinamika yang berdampak terhadap perbaikan perfusi jaringan serebral. Tercapainya kestabilan hemodinamika yang diikuti perbaikan perfusi jaringan serebral dapat meningkatkan percepatan pemulihan dan penyembuhan pasien. Terapi musik ini telah banyak diteliti dan digunakan sebagai terapi alternatif dalam dunia keperawatan maupun kesehatan secara umum.
Musik sebagai terapi telah dikenal sejak abad ke-4 Masehi dan terus dikembangkan hingga sekarang. Musik sebagai terapi sudah sering dipakai, lewat walkman mini untuk bayi dalam inkubator, untuk menenangkan pasien kesakitan di klinik gigi atau di ruang bersalin, dan pusat-pusat rehabilitasi stroke. Bahkan pada penyakit yang tidak dapat disembuhkan seperti Alzheimer, musik membantu kondisi mental pasien agar tidak makin mundur dan menggali kembali ingatan-ingatan pasien (Intisari, 2005). Di pusat-pusat rehabilitasi di Amerika, musik mars mampu menstimulasi otak pada pasien stroke, yang secara umum ternyata dapat memperbaiki kondisi motorik pada pasien dengan stroke (Anonim, 2005).

Kemper dan Danhauer (2005) menyatakan musik juga dapat memberikan efek bagi peningkatan kesehatan, mengurangi stres, dan mengurangi nyeri. Musik efektif untuk menurunkan kecemasan dan meningkatkan perasaan positif pada pasienpasien medikal dan bedah. Musik berpengaruh terhadap mekanisme kerja sistem syaraf otonom dan hormonal, sehingga secara tidak langsung dapat berpengaruh terhadap kecemasan dan nyeri. Pasien yang diterapi dengan menggunakan musik akan merasa lebih rileks dan tenang. Efek relaksasi yang didapat melalui terapi musik tersebut akan berpengaruh terhadap stabilitas dan penurunan tekanan darah, nadi, dan pernapasan.

Beberapa penelitian tentang manfaat terapi musik bagi kesehatan manusia di atas telah banyak dikembangkan di berbagai negara terutama di Eropa dan Amerika. Hasil penelitian terapi musik pada pasien bukan koma menunjukkan efek positif terhadap status hemodinamika, gambaran EKG, dan pernapasan. Seseorang yang mendengarkan musik yang sesuai maka denyut nadi dan tekanan darahnya dapat menurun dan stabil, gelombang otak melambat, pernapasan melambat, dan otototot menjadi rileks (Syifa, 2004).

Informasi yang dapat diperoleh tentang efek atau manfaat terapi musik pada pasien koma masih sangat sedikit. Oleh karena itu, penulis ingin meneliti tentang pengaruh terapi musik terhadap status hemodinamika pasien koma di ruang Intensive 
Care Unit/ICU sebuah rumah sakit di Lampung. Penelitian ini bertujuan mengetahui pengaruh terapi musik terhadap status hemodinamika pada pasien koma dengan mengidentifikasi perbedaan status hemodinamika (tekanan arteri rerata/Mean Arterial Pressure (MAP), frekuensi jantung, dan frekuensi pernapasan) sebelum dan sesudah terapi musik.

\section{METODE PENELITIAN}

Penelitian ini menggunakan desain kuasi experimen one group pre-post test, dengan jumlah sampel 21 pasien koma yang ditetapkan dengan teknik consecutive sampling. Adapan kriteria inklusi sampel antara lain: pasien koma dengan Glasgow Coma Scale/GCS 3-7, diagnosis medis cidera kepala berat/CKB atau stroke hemoragik, dirawat hari ke-4 sampai 5, pasien usia dewasa, saturasi oksigen $95 \%$ atau lebih, kadar kalium dan natrium normal, dan bersedia dijadikan responden. Sedangkan kriteria eksklusi meliputi tidak dilakukan tindakan lain selama terapi musik, suhu ruangan $20-22^{\circ} \mathrm{C}$, tidak memiliki riwayat gangguan pendengaran, tidak ada trauma pada telinga, dan hasil pemeriksaan $C T$ scan tidak menunjukkan kerusakan pada daerah temporalis.

Proses pengumpulan data dilaksanakan selama bulan Mei dan Juni 2007 di ruang ICU sebuah RS di Lampung. Terapi musik dengan musik instrumentalia healing sound dilakukan antara pukul 12.00-16.00 WIB. Status hemodinamika berupa tekanan darah, frekuensi jantung, dan pernapasan pada pasien dipantau sebelum dan setelah terapi musik selama 90 menit. Waktu 90 menit merupakan waktu yang diperkirakan dapat memberikan efek bermakna. Waktu 90 menit ini juga merupakan waktu yang pernah digunakan pada studi yang dilakukan oleh Raymond Bahr, dimana dalam waktu satu setengah jam mendengarkan musik yang lembut memiliki efek terapi yang sama seperti dengan menggunakan obat penenang Valium 10 miligram (Ucup, 2006). Selain itu, prinsip dasar yang harus dipegang dalam pemberian terapi musik adalah bahwa terapi musik yang tepat untuk pasien yang tepat tidak akan memberikan dampak yang membahayakan, walaupun diberikan dalam jangka waktu yang lama (Mucci \& Mucci, 2002).

\section{HASIL PENELITIAN}

Hasil analisis univariat mendapatkan data rerata umur responden adalah 48,05 tahun, dengan umur termuda 22 tahun dan tertua 60 tahun. Nilai median untuk GCS adalah 6 dengan GCS terendah 4 dan tertinggi 7. Analisis bivariat rerata tekanan arteri, frekuensi jantung, dan frekuensi pernapasan sebelum dan sesudah terapi musik digambarkan nada tahel 1 .

\begin{tabular}{lcccc}
\hline Variabe & Mean & $\begin{array}{c}\text { Std. } \\
\text { Deviasi }\end{array}$ & SE & $p$ valus \\
\hline MAP & & & & \\
- Sebe bm & 99,12 & 1871 & 4,08 & 0,31 \\
- Segudah & 92,32 & 1175 & 2,56 & \\
\hline
\end{tabular}

Tabel 1 menunjukkan gambaran rerata MAP sebelum terapi musik sebesar 99,12 mmHg (SD $18,71 \mathrm{mmHg}$ ) dan rerata MAP sesudah terapi musik sebesar 92,32 mmHg (SD 11,75 mmHg). Hasil analisis lebih lanjut dengan menggunakan uji $\mathrm{T}$ dependen (paired T test) menyimpulkan bahwa terdapat perbedaan bermakna antara MAP sebelum

\begin{tabular}{lcccc}
\hline \multicolumn{1}{c}{ Variabel } & Mern & $\begin{array}{c}\text { Std. } \\
\text { Deviag }\end{array}$ & SE & pvabue \\
\hline Feluersi & & & & \\
jarturg & & & & \\
- Sebe $\operatorname{lmm}$ & 102,43 & 20,17 & 4,40 & 0,015 \\
- Sesudah & 95,67 & 19,40 & 4,23 & \\
\hline
\end{tabular}

Tabel 2 menunjukkan gambaran rerata denyut jantung sebelum terapi musik sebesar 102,43 kali/ menit (SD 20,17 kali/menit) dan rerata denyut jantung sesudah terapi musik sebesar 95,67 kali/ 
menit dengan standar deviasi 11,75 mmHg. Hasil analisis lebih lanjut menyimpulkan bahwa terdapat perbedaan bermakna antara denyut jantung sebelum

\begin{tabular}{|c|c|c|c|c|}
\hline visbel & Mern & $\begin{array}{c}\text { Sti. } \\
\text { Detiai }\end{array}$ & SE & $p$ vilue \\
\hline $\begin{array}{l}\text { Popss } \\
\text { - Sebelm } \\
\text { - Sesudih }\end{array}$ & $\begin{array}{l}22,75 \\
18,67\end{array}$ & $\begin{array}{l}4,74 \\
5,44\end{array}$ & $\begin{array}{l}1,04 \\
1,19\end{array}$ & 0,000 \\
\hline
\end{tabular}

Tabel 3 selanjutnya memperlihatkan gambaran rerata frekuensi pernapasan sebelum terapi musik sebesar 22,75 kali/menit dengan standar deviasi 4,74 kali/menit. Rerata frekuensi pernapasan sesudah terapi musik sebesar 18,67 kali/menit dengan standar deviasi 5,44 $\mathrm{mmHg}$. Hasil analisis lebih lanjut menyimpulkan bahwa terdapat perbedaan bermakna antara frekuensi pernapasan sebelum dan sesudah terapi musik $(p=0,000)$.

Hasil uji pengaruh faktor-faktor pengganggu terhadap perubahan status hemodinamika (MAP, frekuensi jantung, dan frekuensi pernapasan) pada pasien koma yang diberikan terapi musik dengan regresi logistik ganda memperoleh kesimpulan bahwa secara garis besar faktor-faktor pengganggu tidak berpengaruh terhadap status hemodinamika, kecuali natrium yang berpengaruh terhadap perubahan frekuensi jantung pasien koma yang diberikan terapi musik $(\mathrm{p}=0,047)$.

\section{PEMBAHASAN}

Hasil penelitian tentang pengaruh terapi musik terhadap pasien koma dilakukan terhadap 21 responden. Hasil analisis statistik menunjukkan bahwa terdapat perbedaan yang bermakna antara MAP, frekuensi jantung, dan frekuensi pernapasan sebelum dan sesudah terapi. Ini berarti pemberian terapi musik dengan musik intrumentalia sound healing selama 90 menit memberikan pengaruh yang bermakna terhadap status hemodinamika pada pasien koma khususnya pada kasus CKB dan stroke.

Musik sebagai salah satu terapi keperawatan telah banyak digunakan dalam dunia kesehatan. Ada banyak teori dan hasil penelitian yang telah membahas hal tersebut. Dengan demikian, hasil penelitian ini telah memberikan dukungan yang kuat terhadap eksistensi terapi musik dalam dunia kesehatan, terutama bidang keperawatan. Hasil penelitian sekaligus memperkuat argumentasiargumentasi teoritis beberapa hasil studi tentang terapi musik terdahulu. Hasil penelitian terdahulu menyatakan bahwa instrumentalia yang lembut akan memberikan efek tenang dan menurunkan stres dan kecemasan dengan sangat luar biasa (Mucci \& Mucci, 2002).

Aldridge (1996), Aldridge, Gustorff, dan Hannich (1990), Ansdell (1995), Bright dan Signorelli (1999), Kennelly dan Edwards (1997), serta Rosenfeld dan Dun (1999) melaporkan tentang efek musik terhadap fungsi orientasi pada pasien koma. Observasi terhadap respon orientasi meliputi membuat kontak mata dengan ahli terapi musik dan menganggukan kepala, membuka mata spontan dan meningkatkan pergerakan lengan pasien. Sejalan dengan hal tersebut, Clair (1996) melaporkan bahwa orang yang mengalami demensia tahap lanjut yang difasilitasi dengan musik-musik yang biasa didengarkan memberikan respon orientasi seperti memutar kepala mencari arah bunyi musik, membuka mata dan fokus pada ahli terapi musik, menggerakkan lengan, berbicara, dan mengubah ekspresi wajah dengan ekspresi yang alamiah. Selanjutnya, Shively dan Henkin (1996), Clair dan Ebberts (1997), serta Olderog dan Smith (1999) melaporkan bahwa pada orang yang mengalami penyakit Alzheimer tahap menengah yang diperdengarkan musik-musik yang biasa didengarnya dapat meningkatkan kemampuan orientasi terhadap waktu, tempat, dan orang.

Suara musik intrumentalia yang lembut dan menenangkan diperdengarkan di beberapa ruangan penderita kanker, ICU, dan pusat-pusat terapi untuk meminimalkan dampak dari suara-suara yang negatif di RS. Dampaknya membuat para pasien 
menjadi lebih nyaman, rileks, dan lebih bahagia. Hal itu juga membuat tubuh meraka mengeluarkan getaran pada tingkat yang lebih sehat (Mucci \& Mucci, 2002).

Hasil penelitian terapi musik pada pasien bukan koma juga telah terbukti menunjukkan efek positif terhadap status hemodinamika, gambaran EKG, dan pernapasan. Seseorang yang mendengarkan musik yang sesuai maka denyut nadi dan tekanan darahnya dapat menurun dan stabil, gelombang otak melambat, pernapasan melambat, dan otototot menjadi rileks (Anonim, 2004).

Kemper dan Danhauer (2005) menyatakan bahwa musik dapat mengurangi stres dan nyeri. Musik berpengaruh terhadap mekanisme kerja sistem saraf otonom dan hormonal, sehingga secara tidak langsung dapat berpengaruh terhadap kecemasan dan nyeri. Pasien yang diterapi dengan menggunakan musik akan tampak lebih rileks dan tenang. Efek relaksasi yang didapat melalui terapi musik tersebut akan berpengaruh terhadap stabilitas dan penurunan tekanan darah, nadi, dan pernapasan.Hal tersebut juga sesuai dengan hasil penelitian ini.

\section{KESIMPULAN}

Penelitian ini membuktikan adanya perbedaan yang bermakna antara rerata MAP, frekuensi jantung, dan frekuensi pernapasan sebelum sesudah dilakukan terapi musik di ICU sebuah RS di Lampung. Dengan demikian, terapi musik berpengaruh secara bermakna terhadap status hemodinamika pada pasien koma. Terapi musik dapat digunakan sebagai salah satu intervensi keperawatan pada pasien koma. Terapi musik yang sesuai dapat digunakan dalam upaya untuk melawan stimulus-stimulus yang tidak menyenangkan di ruang perawatan kritis.

Penerapan dan pengembangan intervensi keperawatan terapi musik hendaknya dilakukandan disosialisasikan secara luas. Penelitian selanjutnya dapat dilakukan secara acak dengan melibatkan lebih banyak responden. Komunikasi yang terapeutik dan percakapan-percakapan yang baik kepada pasien koma dalam setiap aktivitas perawatan juga merupakan salah satu aspek yang harus diperhatikan oleh perawat dan petugas kesehatan lainnya dalam berinteraksi dengan pasien koma tersebut (DW, JH).

* Staf Akademik Keperawatan Medikal Bedah Poltekkes Tanjung Karang

** Staf Akademik Keperawatan Medikal Bedah FIK UI

*** Staf Akademik Dasar Keperawatan dan Keperawatan Dasar FIK UI

\section{KEPUSTAKAAN}

Aldridge, D. (1996). Music therapy research and practice ini medicine: From out of the silence. London: Jessica Kingsley Publishers ltd.

Aldridge, D., Gustorff, D., \& Hannich, H.J. (1990). Where am I? Music therapy applied to coma patients. Journal of The Royal Society of Medicine, 83 (1), 345-346.

Anonim. 2005. Terapi penyembuhan dengan musik. http://sales@melodiamusik.com, diperoleh 7 Februari 2007.

.Penyembuhan dengan musik. http://sales@ melodiamusik.com, diperoleh 7 Februari 2007.

.Penyembuhan stroke.http://sales@ melodiamusik.com, diperoleh 7 Februari 2007.

Ansdell, G. (1995). Music for life: Creative music therapy with adults. London: Jessica Kingsley Publishers Ltd.

Bright, R. \& Signorelli, R. (1999). Improving the quality of life in profoundly brain-impaired clients: The role of music therapy. Journal ISMM, 30 (2), 141-144.

Clair, A.A. (1996). Therapeutic uses of music with older adult. Baltimore: Health Professionals Press Inc.

Clair, A.A., \& Ebberts, A. (1997). The effects of music therapy on interactions between family caregivers and their care receivers with late stage dementia. Journal of Music Therapy, 34 (3), 148-164. 
Ghazar, J., \& Chestnut, R. (1997). Coma. http:// www.headinjury.com/ashesord.htm, diperoleh 10 Februari 2007.

Guyton, A.C. (1994). Fisiologi tubuh manusia. Jakarta: Binarupa Aksara.

Guzzetta, C.E. (1999). Effects of relaxation and music therapy on patients in a coronary care unit with presumptive acute myocardial infarction. Heart-Lung Journal, 18 (2), 609616.

Intisari. (2005). Ampuhnya musik. http://intisari. com, diperoleh 7 Februari 2007Kemper,. K.J. \& Danhauer., S.C. (2005). Music as therapy. Southern Medical Journal, 98 (3), 282-288.

Kennelly, J. \& Edwards, J. (1997). Providing music therapy to the unconseious child in the pediatric intensive care unit. The Australian Journal of Music Therapy, 8 (2), 18-29.

Mucci., K. \& Mucci., R. (2002). The healing sound of music: Manfaat musik untuk kesembuhan, kesehatan dan kebahagiaan anda. Jakarta: Gramedia Pustaka Utama.

Olderog, M.K.A. \& Smith, J.M. (1999). The influence of group singing therapy on the behaviour of alzheimer's disease patients. Journal of Music Therapy, 26 (2), 171-207.

Rosenveld, J. \& Dun, B. (1999). Music therapy and children with severe traumatic brain injuries. Journal ISSM, 30 (2), 57-74.

Shively, C. \& Henkin, L. (1996). Music and movement therapy with alzheimer's victims. Music Therapy Perpectives, 3, 56-58.

Syifa, B. (2004). Menumbuhkan kreativitas berpikir, http://myquran.com, diperoleh 25 Januari 2007.

Kerja adalah wujud nyata cinta. Jika kita tak dapat bekerja dengan kecintaan namun hanya dengan kebencian, lebih baik tinggalkan pekerjaan itu,lalu duduklah di gerbang rumah ibadah untuk menerima derma dari mereka yang bekerja dengan suka cita

(Kahlil Gibran)

Ketahuilah, hal-hal terindah di dunia ini terkadang tak bisa terlihat dalam pandangan atau teraba dengan sentuhan; mereka hanya bisa terasakan dengan hati.

(Helen Keller)

Hidup tidak mudah bagi siapapun. Tapi kita harus mempunyai kegigihan dan percaya pada diri sendiri. Kita harus percaya bahwa kita diberi suatu bakat dan berapapun pengorbanannya, kita harus mendapatkannya .

(Marie Curie) 